\title{
SCENARIO-DRIVEN TECHNOLOGY FORESIGHT FOR BIM-ASSISTED GREEN CONSTRUCTION TECHNOLOGY
}

\author{
JOHN PAUL DAVID, GLEN IMBANG, JEANELLA FE CRUZ-ARREZA, JET LAWRENCE BELBES, \\ KEVIN CAPA, JOANNE FAYE CAPARAS, DARA DE VERA, MEG MABUTI, CANDY MAE MARISTELA, \\ JOHN BLAS RAMOS, RONELL SIGUA \& AIKO TOMIZAWA \\ Technology Management Center, University of the Philippines Diliman, Philippines
}

\begin{abstract}
The present study aims to discuss the concept of technology foresight, mainly focusing on building information modelling-assisted green construction technology in the Philippines. Scenario-building is a widely used foresight technique based on the analysis and understanding of status quo and historical trends that can be deemed relevant on forecasting how the green construction technology may evolve. Herein includes the correlation between the general notion of green construction industry and implications of political, economic, social, technological, and environmental factors. This paper is an effort to push for the principle, stages, and methods needed in order to achieve building information modelling-assisted green construction theory in the Philippines.
\end{abstract}

Keywords: Philippine foresight, green construction, technology foresight, building information modelling foresight.

\section{INTRODUCTION}

Majority of the construction design in the Philippines still uses traditional construction methods that grew threats in the notion of sustainability. The continuous depletion of natural resources is at an alarming level which should prompt the government and the industry itself to create greener solutions. It's sizable impact on climate change shouldn't be taken lightly and we should opt to use environmentally responsible practices especially in the Philippines where infrastructure is deemed to be one of the key investments of the republic.

\section{METHODOLOGY}

Technology foresight is a strategy to form stories expressing multiple perspective of complex events which they can exploit and assess the emerging technology and possible future environment, a tool for ordering perceptions about alternative future environments and marketability.

Scenario building is a policy analysis tool that describes a possible set of future conditions. The most useful scenarios are those that display the conditions of important variables over time [1]. In this approach, the quantitative underpinning enriches the narrative evolution of conditions or evolution of the variables; narratives describe the important events and developments that shape the variables [2].

\section{FOCAL ISSUE}

Enhanced productivity and efficiency remain to be the major challenges to the construction industry. This may be attributed to the lack of new machinery and technologies that can enhance construction operations and processes. Most construction firms in the Philippines still uses traditional practices that take up impeccable use of natural resources, ignorant of its negative environmental impacts. 


\section{ENVIRONMENTAL SCANNING}

To forecast the possible direction of BIM-assisted green construction technology in the Philippines for current and future lenses through macro-perspective, we used an environmental used an environmental analysis framework (PESTEL analysis) to identify and dissect possible key variables.

- Political

- Build, Build, Build Project of Duterte administration

- Philippines and China relations

- Preference for Chinese contractors over Filipino contractors

- Corruption in infrastructure projects

- Economical

- Growth of Philippine economy

- Growth of construction industry

- Increase in real estate and property development

- Cost of green construction materials

- Cost of infrastructure

- Cost of complementary and supplementary technologies

- Social

- Limited firms using BIM-assisted technology

- Use of traditional construction methods

- UN SDG 11: Sustainable cities and communities [3]

- Old academic programs for tertiary education

- Vocational training and education

- Low manpower in construction industry

- Technological

- Lack of locally developed technologies

- Trends in eco-construction [4]

- Smart communities and cities

- Digitization

- Environmental

- Climate change

- Use of renewable energy

- Sustainable and eco-friendly builds and spaces

- Waste management and resource management principles

- Legal

- Construction industry authority of the Philippines

- Department of Public Works and Highways, CEAP, DTI

- Procurement law

- Building code [5]

- Green building policies [5]

5 CHARACTERIZATION OF KEY PREDICTABLE VARIABLES

In this stage, 18 key predictable variables were identified and characterized from environmental scanning.

- Governance

- $\quad$ Political issues 
- Infrastructure project pipeline

- National policies

- Construction industry related laws and policies

- Construction Industry Authority of the Philippines (CIAP)

- RA 11393 or Advanced Energy and Green Building Technologies Curriculum Act [6]

- Building and Structural Code

- Importation restrictions on construction materials

- Philippine green building private firms and NGOs

- Philippine science and technology policies

- Research and development

- $\quad$ R\&D trends on construction technologies and innovations

- Skilled workforce retention

- Economic growth

- Economic development plan [7]

- Cost of green building materials [8]

- Infrastructure cost

- Technology adoption behavior [4]

- Sustainable development policies

- UN Sustainable Development Goal No. 11 [9]

- Implementation of UN SDGs

- Education

- Academic program development [10]

- Vocational training

- Industry standards

- Emerging technologies

- Emerging new construction materials [11]

- Emerging new and eco-friendly construction materials [11]

- Innovation in the construction industry

- Climate change

- Eco-friendly practices

- Use of renewable energy

- Waste management and resource management principles

\section{CHARACTERIZATION OF CRITICAL UNCERTAINTIES}

This stage characterized vital factors that influences uncertainties for BIM-assisted green construction technology.

- International relations

- International conflicts

- Local/global financial crisis

- Climate change

- Social and political conflicts

- Pandemic of disease

- Emergence of more sophisticated technologies

- Scarcity of locally grown or sourced materials

- Natural disasters/calamities 


\section{CLUSTERING OF VARIABLES}

The clustering of variables is mainly based on the PESTEL framework giving us a more encompassing classification of key predictable variables funneled from the environmental scanning stage. Political and legal forces are merged into one category since most variables under this parameter are overlapping. We have used trends and technology to group variables of emerging trends that are not technological in nature. The cultural aspect is integrated with the social forces. Variables that were identified though Porter's Five Forces and SWOT analysis were mostly clustered under economic and technological forces.

1. Political and legal forces consists of governance; construction industry related laws and policies; and Philippine science and technology policies

2. Economic forces consists of skilled workforce retention; economic growth; economic development plan; cost of green building materials; and infrastructure cost

3. Socio-cultural forces, on the other hand consists of technology adoption behavior; sustainable development policies; education; industry standards

4. Trends and technological forces includes emerging technologies; emerging new construction materials; emerging eco-friendly materials; and innovation in the construction industry

5. Environmental forces has variables such as climate change and eco-friendly practices

\section{RANKING OF VARIABLES FOR KEY DRIVING FORCES}

The ranking of key predictable variables is based on a cross comparison method observed with how the US, UK and Australian construction industry adopted BIM technology and green construction in designing and building. The key driving force in these markets are laws and regulations requiring LEED certification and government reinforcement. Political and legal forces are placed at a more direct connection to impact green construction technology.

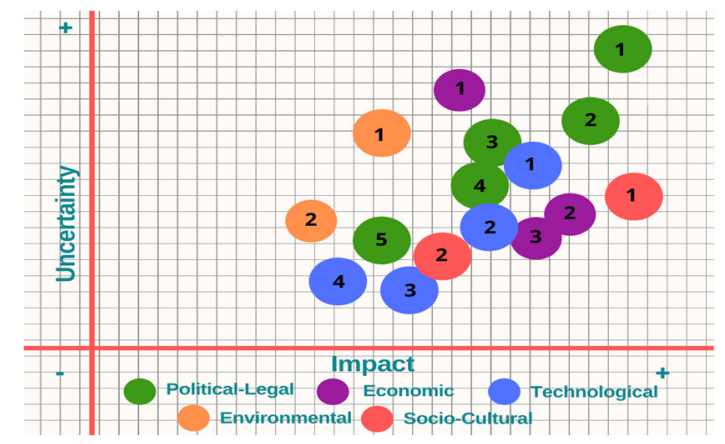

Figure 1: Scatter plot of KPVs based in uncertainty and impact.

Based on the scatter plot (Fig. 1), KPVs under political and legal forces are ranked higher reflecting governance, laws, and policies high uncertainty and high impact characteristics. KPVs under political and legal cluster based on uncertainty and impact are: (1) Laws and policies related to construction; (2) Governance; (3) Economic development plan; (4) Science and tech policy; and (5) Sustainable development policy. KPVs under economic cluster based on uncertainty and impact are: (1) Economic growth; (2) Cost of new construction materials; and (3) Cost of infrastructures. KPVs under economic cluster based on uncertainty and impact are: (1) Technology adoption behavior; (2) Innovation; (3) Emerging tech in 
construction; and (4) Industry standards. KPVs under environmental cluster based on uncertainty and impact are: (1) Climate change; and (2) Eco-friendly practices. KPVs under environmental cluster based on uncertainty and impact are: (1) Technology adoption behavior; and (2) Education.

\section{SELECTION OF SCENARIO LOGICS}

Based on the ranking and plotting on the scatter graph of KPVs based on five clusters, three scenarios were formulated in relation to the development of green construction technology.

\subsection{Scenario Logic 1}

Stricter implementation of the Green Building Act and Building Code of the Philippines and improved importation of green construction technology instigated by the shifting of global industry standards towards sustainability and cost-efficiency. There are three key driving forces in this logic namely, laws and policies related to construction; governance; and technology adoption behavior (Fig. 2).

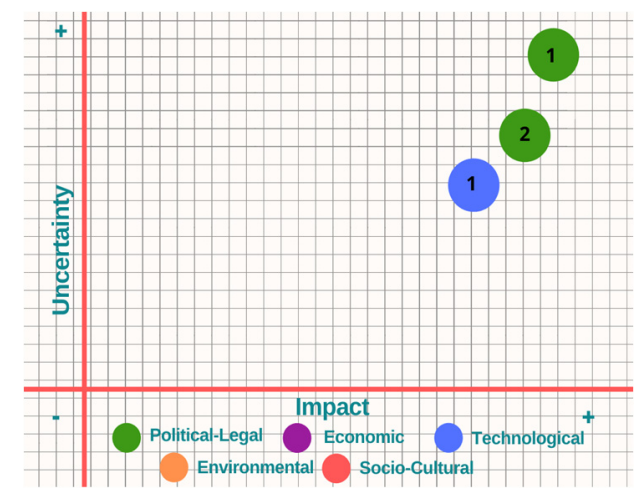

Figure 2: Scatter plot for Scenario Logic 1.

\subsection{Scenario Logic 2}

Economic growth is driving the formation of more megacities and a more mature national innovation system supporting $\mathrm{R} \& \mathrm{D}$ and the adoption of new technologies for environmentally sustainable construction. Key driving forces in this logic are as follows: economic growth, economic development plan, science and tech policy, and technology adoption behavior (Fig. 3).

\subsection{Scenario Logic 3}

Harmonized economic development plan and national innovation system/policy with integrated programs for housing and urban development as the main drive for green/sustainable construction. This logic consists of key driving forces such as an economic development plan, science and technology policy, cost of new construction materials, cost of infrastructure, innovation, and technology adoption behavior (Fig. 4). 


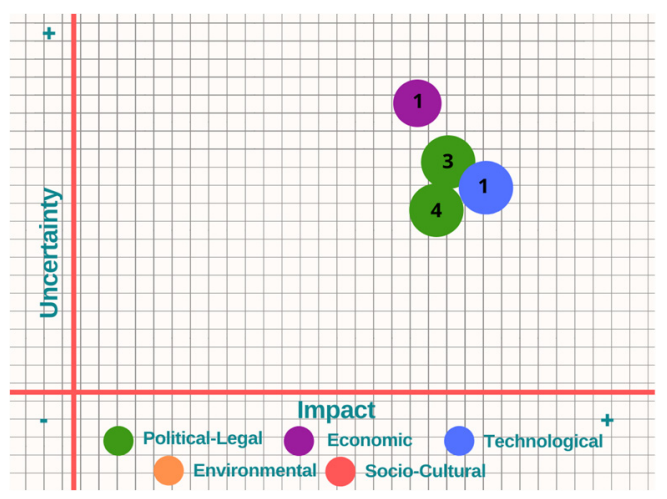

Figure 3: Scatter plot for Scenario Logic 2.

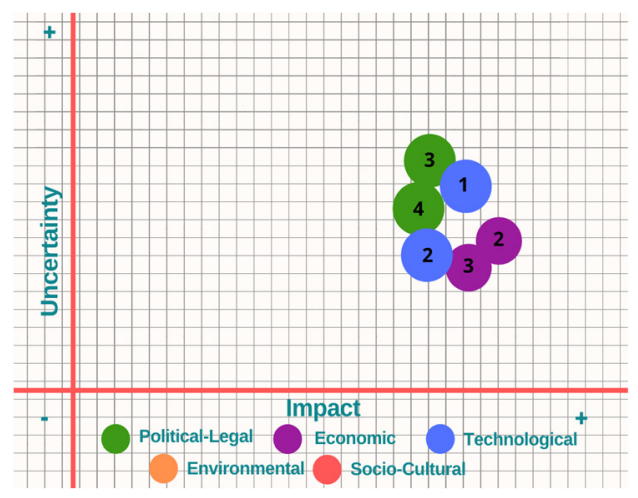

Figure 4: Scatter plot for Scenario Logic 3.

\section{DEVELOPMENT OF SCENARIO}

The main accounts of scenario planning with regards to green construction technology are green building movement, sustainable megacities and communities. and harmonized innovation and development plan.

\subsection{Scenario 1: Green building movement}

Stricter implementation of the Green Building Act and Building Code of the Philippines and improved importation of green construction technology instigated by the shifting of global industry standards towards sustainability and cost-efficiency.

Duterte's Build, Build, Build programs are good venues for the implementation of GB Code. Though the government only completed nine out of 75 priority projects which is part of the Php 8T major infrastructure initiative. Based on the article published in Inquirer last 23 November, DPWH alone is implementing at least 20,000 projects under the Build, Build, Build program [12]. 
10.2 Scenario 2: Sustainable megacities and communities

Economic growth driving the formation of more megacities and a more mature national innovation system supporting $\mathrm{R} \& \mathrm{D}$ and the adoption of new technologies for environmentally sustainable construction.

An article by World Green Building Council's Dominika Czerwinska outlined how green buildings can help achieve Sustainable Development highlighting the positive economic impact of green buildings [13]. It mentioned of affordable and clean energy; decent work and economic growth; industry, innovation and infrastructures; and sustainable communities and cities.

\subsection{Scenario 3: Harmonized innovation and development plan}

Harmonized economic development plan and national innovation system/policy with integrated programs for housing and urban development as key driver for green/sustainable construction

The application of green construction technology in developing facilities and structures is gaining popularity across the globe. Green technology makes buildings more energy-efficient and sustainable. Also, green technology is becoming more affordable in the country to encourage everyone to move towards a sustainable lifestyle. With the stricter implementation of the government in imposing the usage of green technology, we will be able to achieve a more productive lifestyle with energy efficiency and sustainability across infrastructures. Government collaboration with R\&D institutions to continuously enhance and innovate the existing methods and technological means of green technology that would boost the industry through introducing new and improved ways of the technology application.

\section{ASSESSMENT OF SCENARIO COHERENCE}

\subsection{Scenario 1: Green building movement}

Stricter implementation of the Green Building Act and Building Code of the Philippines and improved importation of green construction technology instigated by the shifting of global industry standards towards sustainability and cost-efficiency.

1. Implementation rules and regulations and corresponding processes should be clear and streamlined for easier adoption and compliance of private institutions and firms.

2. Government processes should be regularly reviewed and updated to incorporate changes in the standards and still keep up with the evolution of the industry.

3. Governance is a key factor to avoid corrupt practices and red tape.

4. Implement programs to encourage regional cooperation into the adoption and exchange of green construction products, technologies, and skills.

\subsection{Scenario 2: Sustainable megacities and communities}

Economic growth is driving the formation of more megacities and a more mature national innovation system supporting $\mathrm{R} \& \mathrm{D}$ and the adoption of new technologies for environmentally sustainable construction.

1. Implementation rules and regulations and corresponding processes should be clear and streamlined for easier adoption and compliance of private institutions and firms. 
2. Government and private institutions should create infrastructure to sustain and support Green technology.

3. Encourage house owners to adapt and use renewable energy. Increased awareness on the benefits of green technology.

4. Budget allocation to support R\&D. Possible tax incentive to encourage the use of green technology.

\subsection{Scenario 3: Harmonized innovation and development plan}

Harmonized economic development plan and national innovation system/policy with integrated programs for housing and urban development as key drivers for green/sustainable construction.

1. Government

a. Continuous and stricter implementation of laws (Green Building Act and Building Code)

b. Government programs encouraging green technology

c. Using and adopting green technology to government policies and programs

2. Academe

a. Ensure curriculum for green technology is implemented and tools and technologies for teaching are present

b. Basic and applied research concerning green technology should be intensified

3. Private institution

a. Reinvest back its profits and take advantage of government programs on green construction

b. Streamlining technology transfer between the academe and private firms

\section{ASSESSMENT OF IMPLICATIONS OF SCENARIOS FOR STRATEGIC PLANNING}

This stage assesses the implications of each scenario using SWOT/TOWS matrix. For each scenario, the strengths, weaknesses, opportunities and threats were identified. Afterwards, the TOWS matrix was formed on each scenario to determine the actions that can be done to use the strengths to take advantage of the opportunities, to take advantage of the strengths to avoid the threats, to use opportunities to overcome weaknesses, and to minimize weaknesses to avoid the threats.

\subsection{Scenario 1}

Stricter implementation of the Green Building Act and Building Code of the Philippines and improved importation of green construction technology instigated by the shifting of global industry standards towards sustainability and cost-efficiency.

External opportunities (O)

- Increase in early adopters of BIM technology and green construction technology

- Bigger market for green construction technology

External threats (T)

- Increase in early adopters of BIM technology and green construction technology

Internal strengths $(\mathrm{S})$

- Cost-effective 
- Mandated by government

- Easier adoption with government support

Internal weakness $(\mathrm{W})$

- Possibility of weak governance

- Few skilled professionals in green construction industry

Strength/opportunity (SO)

- Reinforced capability building of human resources to adopt to growing industry of green technology

- Induce effective marketing activities to attract more customers

Strength/threat (ST)

- Capitalize in skill enhancement to be the preferred construction company with green technology

- Create outstanding portfolio of green construction

Weakness/opportunity (WO)

- Conduct seminars/trainings to enhance skills in green construction technology

- Ensure compliance to government regulations about green construction technology

Weakness/threat (WT)

- Recruit highly skilled BIM professionals

- Transform employees to be skilled in green construction technology

\subsection{Scenario 2}

Economic growth driving the formation of more megacities and a more mature national innovation system supporting $\mathrm{R} \& \mathrm{D}$ and the adoption of new technologies for environmentally sustainable construction.

External opportunities $(\mathrm{O})$

- Creation of more advanced green construction technology

- Economic growth

- Improved innovation system

External threats $(\mathrm{T})$

- Entry of more competitors

Internal strengths $(\mathrm{S})$

- Utilization of renewable energy

- Strong partnership and support between government and private firms

- Formulation of R\&D strategies

Internal weakness (W)

- In general, national innovation system in Philippines is not yet that strong

Strength/opportunity (SO)

- Support government programs to utilize renewable energy

- Create internal programs to launch partnered programs with government to promote green technology

Strength/threat (ST)

- Capitalize in skill enhancement to be the preferred construction company with green 
technology

- Create outstanding portfolio of green construction

- Ensure compliance to government policy

Weakness/opportunity (WO)

- Create R\&D center to help boost innovation in the country

Weakness/threat (WT)

- Enhance capability to be proficient in green construction technology

\subsection{Scenario 5}

Harmonized economic development plan and national innovation system/policy with integrated programs for housing and urban development as key driver for green/sustainable construction.

External opportunities (O)

- Enhanced housing and urban development

- Inclusion of green construction technology to economic development plan

- Creation of more projects

External threats $(\mathrm{T})$

- Increase influence of private sector and decreased government influence

Internal strengths $(\mathrm{S})$

- Strong collaboration with government, private sector and academe

- Investment opportunities

- Budget allocation on green technology

- More safety construction

Internal weakness (W)

- Difficulties in dealing with government process

Strength/opportunity (SO)

- Include industry-academe immersion programs to promote green construction technology

- Include programs in academe that support government policy for green and sustainable construction

Strength/threat (ST)

- Conduct more technology transfer among government, private sector and academe

- Enhance policies that will protect government/public interest

Weakness/opportunity (WO)

- Encourage and support the government to do process review

Weakness/threat (WT)

- Encourage and support the government to do process review

\section{REFERENCES}

[1] Imbang, G., Technology Foresight - Scenario Building, University of the Philippines Technology Management Center, 2019. https://tmc.up.edu.ph. 
[2] Moniz, A., Methods for scenario-building: it's importance for policy analysis. Proceedings of Workshop on Innovative Comparative Methods for Policy Analysis, pp. $1-18,2005$.

[3] United Nations, Sustainable Development Goal 11, 2016. https://sustainabledevelopment.un.org/about.

[4] Montoya, M., Green Building Fundamentals, Pearson: New Jersey, 2011.

[5] Philippine Green Building Council, BERDE Technical Manual for Existing Buildings, 1st ed., Taguig City, 2011.

[6] Presidential Decree (P.D.) No. 1096, Adopting a National Building Code of the Philippines (NBCP), 1977.

[7] National Economic Development Authority, Ambisyon Natin 2040, National Economic Development Authority: Pasig, 2016.

[8] United States Environmental Protection Agency, Green building. www.epa.gov/greenbuilding/pubs/about.htm. Accessed on: 22 Dec. 2019.

[9] Commission on Audit, Performance audit of preparedness for implementation of Sustainable Development Goals, 2018. www.coa.gov.ph/phocadownloadpap/ userupload/Sustainable_Devt_Goals/Performance_Audit_Report_on_SDG_ Preparedness.pdf.

http://ray.dilg.gov.ph/files/national_building_code_of_the_philippines.pdf.

[10] Ismail, N.A., Chiozzi, M. \& Drogemuller, R., An overview of BIM uptake in Asian developing countries, 2017. https://aip.scitation.org/doi/pdf/10.1063/1.5011596.

[11] Nguyen, B.K., TPSI: Tall-building projects sustainability indicator. PhD thesis, University of Sheffield, 2011.

[12] Remo, A., "Build, build, build" a boon to developers, 2019. https://business.inquirer.net/283899/build-build-build-a-boon-to-developers. Accessed on: 23 Dec. 2019.

[13] Czerwinska, D., Green building: Improving the lives of billions by helping to achieve the UN Sustainable Development Goals, 2017. www.worldgbc.org/news-media/ green-building-improving-lives-billions-helping-achieve-un-sustainabledevelopment-goals. Accessed on: 22 Dec. 2019. 